\title{
Fatigue/utmattelse etter traumatisk hjerneskade og hjerneslag
}

\begin{abstract}
BAKGRUNN Fatigue/utmattelse kan defineres som en opplevelse av langvarig eller tilbakevendende tretthet og redusert kapasitet for mental og/eller fysisk aktivitet. Tilstanden er vanlig etter ervervet hjerneskade. I artikkelen gis en oversikt over kunnskapsstatus om utmattelse etter hjerneslag og etter traumatiske hjerneskader.
\end{abstract}

KUNNSKAPSGRUNNLAG En vurdering av eksisterende litteratur, inkludert litteratursøk, samt vår kliniske erfaring ligger til grunn for innholdet i artikkelen.

RESULTATER I eksisterende undersøkelser er det brukt varierende definisjoner av tilstanden og det er anvendt ulike kartleggingsverktøy. Forekomsten av utmattelse etter hjerneslag eller traumatisk hjerneskade er usikker på grunn av ulike inklusjonskriterier og kartleggingsmetoder og fordi ulikt måletidspunkt kan gi ulike prevalenstall. I flere arbeider anslås forekomsten til å ligge mellom $50 \%$ og $70 \%$. Vår kunnskap om de patologiske mekanismene er svært begrenset. Både premorbide, sosiodemografiske, slag-/traumerelaterte og komorbide faktorer spiller inn på hvordan pasienten oppfatter tilstanden. Blant anvendte behandlingstiltak er psykoedukasjon, aktivitetsregulering, fysisk trening og behandling av komorbide tilstander. Det er også gjort forsøk med medikamentell behandling, foreløpig uten overbevisende resultater.

FORTOLKNING Utmattelse er vanlig hos hjerneslagpasienter og pasienter med traumatiske hjerneskader og begrenser ofte i betydelig grad deres hverdag. Vår viten om patologiske mekanismer og behandlingstiltak er mangelfull, og pasientpopulasjonen er heterogen. Behandlingen er individuelt tilpasset og har som mål at den enkelte skal kunne bruke sin begrensede kapasitet på en mest mulig hensiktsmessig måte.

Fatigue - en tilstand av utmattelse - ses ved blant annet revmatiske og nevrologiske sykdommer, ved kreft, infeksiøse tilstander og psykisk sykdom. Vi har valgt å konsentrere oss om utmattelse etter traumatiske hjerneskader eller hjerneslag. Dette gjenspeiler hvor tyngden av rehabiliteringen ligger ved hjerneskadeavdelingen i vårt sykehus. Det kliniske uttrykket ved disse sykdomstilstandene er til forveksling likt og berører pasientene på samme måte. Mange fellestrekk rettferdiggjør en felles artikkel (1).

«Utmattelse» er mer dekkende enn «tretthet» for det pasientene opplever av energitomhet. Tilstanden er karakterisert av at det skal uforklarlig lite fysisk og/eller mental anstrengelse til før utmattelsen inntrer - den kan beskrives som en forsterkning av normal tretthet. Fatigue/utmattelse skiller seg fra en tilstand av apati - da ønsker man ikke å være aktiv. Pasientene ønsker å være aktive, men har vansker med å starte eller opprettholde en aktivitet selv om de er motiverte (2). I klinisk praksis oppleves det at hos noen pasienter kan selv ikke den sterkeste motivasjon oppveie vedkommendes uttalte følelse av utmattelse.

I vår kliniske praksis erfarer vi for eksempel at pasientene har betydelig redusert arbeidskapasitet. Noen faller helt ut av arbeidslivet. Mange får innskrenket sitt sosiale liv og prioriterer ned/bort normal selskapelig aktivitetsnivå betydelig.

\section{Kunnskapsgrunnlag}

Vi gjennomførte søk i Medline etter relevante engelskspråklige artikler fra de siste 15 år frem til 1.7. 2013 med MeSH-søkeordene «fatigue AND stroke OR Brain Injury OR Brain Diseases OR Brain Concussion OR Brain Hemorrhage, Traumatic OR Brain Injury, Chronic OR Diffuse Axonal Injury». Søket resulterte i 675 treff. Vi søkte i Google Scholar med tilsvarende søkeord («altitittel: fatigue «traumatic brain injury»»» og «altitittel: fatigue stroke») - 188 treff. «Sitert av»-funksjonen ble brukt på artikler vi fikk frem gjennom søket.

Det ble under søket ikke lagt restriksjoner med tanke på artikkeltype. Tittelen (og hvis den ikke var entydig - sammendrag av resultatene) ble lest og vurdert med tanke på relevans - det vil si om den enkelte artikkelen hadde fatigue/utmattelse ved hjerneslag eller traumatisk hjerneskade enten som hovedtema eller i det minste som en vesentlig del av innholdet (AS og FB).

Etter gjennomlesing ble litteratursamlingen ytterligere supplert med noen enkeltartikler fra referanselistene. Prosessen resulterte i totalt 71 artikler, hvorav 19 omhandlet kartleggingsverktøy ved fatigue/ utmattelse, 21 utmattelse etter hjerneslag, aktivitet. Mange må redusere sitt fysiske

\section{Andreas Schillinger}

Kognitiv rehabiliteringsenhet (KReSS)

Sunnaas sykehus

\section{Frank Becker}

frank.becker@sunnaas.no

Seksjon for hjerneskader

Sunnaas sykehus

og

Institutt for klinisk medisin

Universitetet i Oslo

Se også kunnskapsprøve

på www.tidsskriftet.no/quiz

\section{HOVEDBUDSKAP}

Utmattelse er et vanlig symptom etter hjerneslag og traumatisk hjerneskade

Manglende konsensus om definisjon og valg og bruk av vurderings- og måleverktøy gjør at prevalenstallene spriker

Vår kunnskap om de patologiske mekanismene er svært begrenset

Dagens behandlingsalternativer mangler tilstrekkelig kunnskapsgrunnlag 
Tabell 1 Sentrale termer

\begin{tabular}{|c|c|c|}
\hline Term & Forklaring & Førsteforfatter (referanse) \\
\hline Primær fatigue & Fatigue som tilskrives underliggende sykdom & Cantor (4) \\
\hline Sekundær fatigue & Fatigue som skyldes komorbide tilstander & Cantor (4) \\
\hline Subjektiv fatigue & Måles ved selvrapportering & Hoang (3) \\
\hline Objektiv fatigue & $\begin{array}{l}\text { Objektivt målbart på vedvarende fysisk ytelse eller } \\
\text { nevropsykologisk testing }\end{array}$ & Hoang (3) \\
\hline Perifer fatigue & Vedrører det perifere nervesystem, objektivt målbart & Chaudhuri (2), Cantor (4), Chaudhuri (6) \\
\hline Sentral fatigue & Vedrører sentralnervesystemet, subjektiv opplevelse & Chaudhuri (2), Cantor (4), Chaudhuri (6) \\
\hline \multicolumn{3}{|l|}{$\begin{array}{l}\text { Ulike dimensjoner knyttet til begrepet fler- } \\
\text { dimensjonalt symptom: }\end{array}$} \\
\hline Generell fatigue (generell dimensjon) & Subjektiv samlet opplevelse av utmattelse & Ingles (7), Staub (8), Ericsson (9) \\
\hline Fysisk fatigue (fysisk dimensjon) & Fatigue ved fysisk anstrengelse & Chaudhuri (2), Ericsson (9), Chalder (10) \\
\hline Mental fatigue (kognitiv dimensjon) & Fatigue ved kognitiv anstrengelse & Chaudhuri (2), Ericsson (9) \\
\hline Psykisk fatigue & Fatigue som tilskrives motivasjonelle problemer & Chaudhuri (2), Ericsson (9) \\
\hline Aktivitetsdimensjon & Fatigue ved deltakelse sosialt liv, fritid, arbeidsliv & Ericsson (9) \\
\hline
\end{tabular}

18 utmattelse etter traumatisk hjerneskader og 13 utmattelse generelt eller ved andre tilstander.

Disse ble lest i fulltekst og resultatene skjønnsmessig vurdert med tanke på metodologisk kvalitet, inkludert kvalitet på beskrivelsen av fremgangsmåten, pasientgrunnlag (både når det gjelder definisjon, utvelgelse og antall), kartleggingsverktøy og effektmål som ble brukt m.m. (AS). Vi la spesielt vekt på artikler der kvaliteten ble vurdert som god. Videre bygger vi på våre egne kliniske erfaringer.

\section{Hva er fatigue/utmattelse?}

Tilstanden oppfattes av de fleste artikkelforfatterne som et flerfasettert (multifaktorielt) symptom (3) som kan romme elementer fra komorbide tilstander (4). Overlapping i opplevelse gjør det problematisk å skille tilstanden fra for eksempel depresjon.

Det hadde vært ønskelig med en presis definisjon av symptomet, men det finnes ingen konsensus om en definisjon av fatigue/utmattelse ved hjerneslag (5) eller traumatisk hjerneskade. MeSH- definisjonen (Medical Subject Headings) er «the state of weariness following a period of exertion, mental or physical, characterized by a decreased capacity for work and reduced efficiency to respond to stimuli».

Vi har ikke funnet noen norsk omforent definisjon, men foreslår «en subjektiv opplevelse av langvarig eller stadig tilbakevendende tretthet og redusert kapasitet for mental og/eller fysisk aktivitet».

Noen sentrale termer som omhandler sider ved begrepet fatigue/utmattelse er samlet i tabell $1(2-4,6-10)$.

\section{Vurderingsverktøy/ \\ måleinstrumenter}

Ved fatigue/utmattelse føler pasienten seg sliten. Tidlige forsøk fra 1920-årene og fremover på å angi grad har vært kontroversielle. Siden dette er en subjektiv opplevelse og ikke entydig definert, er det vanskelig å måle graden objektivt. De siste 30 år har man likevel tatt i bruk ulike vurderingsverktøy. De to vanligste hovedtyper av måleinstrumenter er visuelle analoge skalaer (VAS) (11) og Likertliknende selvevalueringsskjemaer (12).

Det er ikke utviklet måleverktøy spesifikt for evaluering av fatigue/utmattelse etter hjerneslag. Hver forfatter synes å velge måleinstrument på egne premisser. I ulike arbeider er det evaluert opptil 50 ulike selvevalueringsskjemaer $(13,14)$. Noen har også kommet med spesifikke anbefalinger (13) om hvilke skjemaer som er å foretrekke.

Det er utviklet et par skjemaer for traumatiske hjerneskader, The Barrow Neurological Institute (BNI) Fatigue Scale (15) og The Cause of Fatigue (COF) Questionnaire (16), men også i arbeider om pasienter med traumatisk etiologi brukes et bredt utvalg av skjemaer som i utgangspunktet er utviklet for andre sykdommer. Vurderingsverktøyene er enten endimensjonale, måler bare én side ved tilstanden, for eksempel alvorlighetsgrad, eller flerdimensjonale (tab 1). I tabell $2(10,17-23)$ beskrives kort noen av de mest brukte skalaene ved slag og traumatisk hjerneskade.

\section{Forekomst etter hjerneslag og traumatiske hjerneskader}

Prevalensnivået av fatigue/utmattelse i den generelle befolkning er estimert i noen arbeider. En engelsk (24) og en norsk (25) undersøkelse ga prevalenstall på henholdsvis $18,3 \%$ og $11,4 \%$. Bay \& de Leon har etter litteraturgjennomgang angitt forekomsten i den generelle befolkning til mellom $14 \%$ og $22 \%$ (26).

Det finnes en rekke undersøkelser som angir prevalens av utmattelse etter hjerneslag og etter traumatisk hjerneskade. Det er et bemerkelsesverdig sprik i tallene. For utmattelse etter hjerneslag er det beskrevet prevalens helt ned i 23,4\% (27), mens den i de fleste undersøkelsene varierer mellom $51 \%$ og $72 \%(3,7,28-30)$. For utmattelse etter traumatisk hjerneskade varierer prevalensen mellom $32,4 \%$ og $73 \%(31-35)$, men en kilde angir et spenn på $16-80 \%$ for prevalenstall (36). Tallene kan virke forvirrende, men det generelle bildet er likevel at tilstanden er vanlig etter hjerneslag og traumatisk hjerneskade. Dette er også inntrykket fra vår kliniske hverdag.

\section{Fatigue, assosierte faktorer og komorbiditet}

Forholdet mellom utmattelse (etter hjerneslag og etter traumatisk hjerneskade) og assosierte faktorer ( $\operatorname{tab} 3)(3,7,26-29,36-42)$ er forskningsmessig et noe uoversiktlig område. Det finnes en rekke undersøkelser der man har sett på dette, og det er til dels motstridende funn. Best avklart er forholdet mellom utmattelse og sosiodemografiske fakto- 
Tabell 2 Vurderingsverktøy

\begin{tabular}{|c|c|c|c|}
\hline Navn & Dimensjon & Sykdom den er utviklet for & Førsteforfatter (referanse) \\
\hline Visual Analogue Fatigue Scale (VAFS) & Endimensjonal & Generell & Tseng (17) \\
\hline Visual Analogue Scale for Fatigue (VAS-F) & Flerdimensjonal & Generell & Lee (18) \\
\hline Fatigue Severity Scale (FSS) & Endimensjonal & $\begin{array}{l}\text { Systemisk lupus erythematosus, } \\
\text { multippel sklerose }\end{array}$ & Krupp (19) \\
\hline Fatigue Assessment Inventory (FAl) & Flerdimensjonal & Generell & Schwartz 20l \\
\hline Multidimensional Assessment of Fatigue Scale (MAF) & Flerdimensjonal & Leddgikt & Belza (21) \\
\hline Multidimensional Fatigue Inventory (MFI-20) & Flerdimensjonal & Kreft, kronisk utmattelsessyndrom & Smets (22) \\
\hline The Fatigue Questionnaire (FQ) & Flerdimensjonal & Kronisk utmattelsessyndrom & Chalder (10) \\
\hline Fatigue Impact Scale (FIS) & Flerdimensjonal & Multippel sklerose, hypertensjon & Fisk (23) \\
\hline
\end{tabular}

rer, hvor de fleste forfattere ikke finner noen sikker sammenheng.

De fleste finner heller ikke noen sammenheng mellom slag- og traumerelaterte faktorer og utmattelse. Premorbide forhold er ofte lite berørt i de ulike arbeidene, men i et arbeid finner man relasjon mellom premorbid fatigue og utmattelse etter hjerneslag (37).

Minst avklart er forholdet mellom utmattelsestilstanden og komorbide faktorer. Mange arbeider berører dette, men resultatene spriker. Vi er tilbøyelige til å tro at tilstanden samvarierer med slike faktorer (tab 3). Både depresjon, søvnforstyrrelser og kronisk smerte er vanlig (1) og bidrar til det samlede bildet. Samtidig kan utmattelse opptre uavhengig av slike faktorer $(7,28,38)$ og også uten funn av andre symptomer (8).

Et uavklart spørsmål er derfor om utmattelse etter hjerneslag og etter traumatisk hjerneskade alene kan tilskrives komorbide tilstander (sekundær fatigue) eller om hjerneskaden forklarer det helt eller delvis (primær fatigue) (29). Etter vår oppfatning er det mest sannsynlig slik at der utmattelsesfremkallende komorbide tilstander er til stede, gir de et individuelt varierende bidrag, stort eller lite, inn i den samlede opplevelsen, eller de kan forklare tilstanden helt (39). Primær fatigue kan også være en kilde, noen ganger den eneste, til opplevelsen $(8,40)$.

\section{Etiologi}

Etiologien for primær utmattelse etter hjerneslag og etter traumatisk hjerneskade er uklar (40). Forklaringene er hypotesepregede mer enn kunnskapsbaserte. I mestringshypotesen, lagt frem av van Zomeren og medarbeidere i 1984 (43), foreslås det at en skadet hjerne må anstrenge seg mer enn en frisk hjerne for å kompensere for kognitive utfall som oppmerksomhetssvikt og redusert psykomotorisk tempo, og at dette resulterer i utmattelse. Hypotesen forutsetter at det finnes kognitive utfall ved mental utmattelse, noe det ikke alltid har latt seg gjøre å vise $(38,41)$.

Men holdepunkter for hypotesen finnes. I en undersøkelse om utmattelse etter traumatisk hjerneskade anvendte man funksjonell MR. Det var økt cerebral aktivitet hos hjerneskadede under utførelsen av en talloppgave, mens det hos friske kontrollpersoner ble registrert tilsvarende redusert cerebral aktivitet (44). Dette ble tolket som uttrykk for at den skadede hjerne sliter for å kompensere for kognitive utfall.

Mer indirekte indisier finnes i et arbeid der man testet vedvarende oppmerksomhet (vigilans) hos friske kontrollpersoner og hos personer med traumatisk hjerneskade. Hjerneskadepasientene fikk påvist større økning av det diastoliske blodtrykket parallelt med mer opplevd utmattelse, et uttrykk for økt testutløst stress og økt mental anstrengelse (31).

Å påvise at skade i spesielle hjerneanatomiske områder forklarer symptomet sentral utmattelse har ikke latt seg gjøre (2,37). Det er foreløpig begrenset støtte for en sammenheng mellom dette og spesifikke forandringer på MR (2). Blant strukturene som mistenkes er hjernestammen og basalgangliene $(6,8,27,38)$, men utmattelse opptrer også ved skade med helt annen lokalisering. Andre hypoteser peker på thalamus, frontale og frontosubkortikale strukturer (2).

Det diskuteres også om nevroendokrine forandringer kan være medvirkende, blant annet malfunksjon $\mathrm{i}$ aksen mellom hypothalamus, hypofyse og binyrer (2). Hormonelle endringer er påvist uten sikker assosiasjon med utmattelse etter traumatisk hjerneskade (36).

\section{Forløp og behandling}

Undersøkelser har vist at utmattelsestilstanden vedvarer og også kan forverres som symptom over tid $(29,41,45)$. Oppfølging over fem år viste endog økende prevalens $\mathrm{i}$ en undersøkelse (35). Tilstanden har også negative konsekvenser for deltakelse i aktiviteter og for livskvalitet $(3,7,26,30)$. I enkelte undersøkelser var utmattelsen noe av det mest plagsomme etter skaden hos nær $50 \%$ av pasientene $(7,28)$. De har derfor et behandlingsbehov. Utfordringen er at det foreløpig finnes lite kunnskapsbasert behandling (46). Siden etiologien er uklar og sannsynligvis multifaktoriell, peker ingen spesifikk behandling seg ut. I stedet benyttes ulike metoder for å bedre pasientenes livssituasjon (1). Følgende aktuelle erfaringsbaserte behandlingstiltak er i bruk:

Aktivitetsregulering. Dette er trolig den foretrukne behandlingsmetoden ved de fleste rehabiliteringsenheter i Norge i dag. Graden av utmattelse etter hjerneslag og etter traumatisk hjerneskade vil variere over tid, det gjelder også dagsformen (47). Vår kliniske erfaring er at på en god dag ønsker pasienten å gjøre opp for foregående dags lave aktivitet og øker aktiviteten utover det tilrådelige. Resultatet er en ny episode med utmattelse. Gjennom bruk av blant dagsplaner og ukeplaner lærer pasientene å utnytte sin begrensede energi mest mulig effektivt og slik forebygge tilbakefall.

Behandling av komorbide tilstander. Dette bør gjøres på indikasjon - depresjon (41), angst, søvnproblemer (39), stress (48) og smerter (3). Slik kan det samlede bildet bedres, mens det er mer usikkert om primærtilstanden også påvirkes $(2,33)$.

Psykoedukasjon (informasjon/opplaering). Dette gis individuelt til pasient og pårørende. Et gruppebasert tilbud kan være et godt alternativ. En randomisert pilotstudie med pasienter med utmattelse gjort omtrent ni måneder etter første hjerneslag (49) viste klar bedring etter et strukturert psykoedukativt opplegg over seks uker, 60 minutter/uke, skreddersydd for å takle utmattelsestilstan- 
Tabell 3 De vanligste assosierte faktorer ved fatigue/utmattelse (vurdert etter utvalgte sentrale arbeider)

$\begin{array}{ll} & \text { Sikker eller sannsynlig assosiasjon, } \\ \text { Faktorer } & \text { føsteforfatter (referanse) }\end{array}$

Sikker eller sannsynlig assosiasjon,

Sosiodemografiske faktorer

Kvinnelig kjønn

Tang (27), Englander (36) ${ }^{1}$, Ponsford (39)1', Cantor (40)'1, Schepers (41)

Høy alder

Schepers (41)

Utdanningsnivå

Sivil status

Slag- og traumerelaterte faktorer

Alvorlighetsgrad

Ingles (7), Cantor (33)1', Ponsford (39) ', Cantor (40)1

Tid siden slag/traume

Hoang (3), Ponsford (39)1', Schepers (41)

Skadelokalisering

Tang (27), Naess (38)
Ingen eller tvilsom assosiasjon,

førsteforfatter (referanse)

\section{Premorbide faktorer}

Premorbid fatigue

Choi-Kwon (37)

\section{Komorbide faktorer}

\begin{tabular}{|c|c|c|}
\hline Depresjon & $\begin{array}{l}\text { Tang (27), Cantor (33)1, Englander (36)1', Choi-Kwon (37), } \\
\text { Naess (38), Ponsford (39) } 1 \text {, Cantor (40) }{ }^{1} \text {, Schepers (42) }\end{array}$ & Hoang (3), Ingles (7), van der Werf (28) \\
\hline Angst & Cantor (33)ํ․ Ponsford (39) ${ }^{1}$ & Naess (38) \\
\hline Søvnforstyrrelser & Ponsford (39) ${ }^{1}$, Cantor (40) ${ }^{1}$, Schepers (41) & Hoang (3) \\
\hline Kronisk smerte & Hoang (3), Englander (36) $)^{1}$, Ponsford (39)', Cantor (40) & \\
\hline Nevrologiske utfall & van der Werf (28), Englander (36)' ${ }^{1}$, Naess (38) & Hoang (3), Ingles (7), Christensen (29), Schepers (41) \\
\hline Dekondisjonering & & Duncan (42) \\
\hline Kronisk stress & Bay $(26)^{1}$ & \\
\hline
\end{tabular}

1 Traumerelaterte referanser

den. Det var større bedring enn i en kontrollgruppe som fikk mer generelle tiltak. Forskjellen var tydelig målt på FSS-skalaen, men ikke signifikant.

Fysisk trening. Det er ikke funnet at fysisk aktivitet hjelper ved utmattelse, men det er heller ikke utelukket $(2,42)$. I vår avdeling har vi valgt å inkludere tilpasset fysisk trening $\mathrm{i}$ behandlingen av disse pasientene.

Medikamentell behandling. Foreløpig finnes det ingen gode studier som viser nytte av medikamenter. Utprøvning av fluoksetin $(46,50)$ og modafinil $(51,52)$ har ikke gitt signifikant bedring.

\section{Diskusjon}

Prevalenstallene for utmattelse i den generelle befolkning kan synes høye. Men den generelle populasjon er ikke synonymt med den friske del av populasjonen. Den inklude- rer også individer med for eksempel depresjon og kroniske somatiske lidelser, herunder også individer som har gjennomgått hjerneslag $(24,53)$. Påfallende er det også at blant friske kontrollpersoner, brukt i kontrollerte studier, varierer prevalensen av utmattelse mye, helt opp i $40 \%$ (40).

Hvem som defineres som «frisk» eller som tilhørende den generelle befolkning, er avhengig av metodevalg og valg av inklusjonskriterier. Likeledes spriker prevalenstallene for forekomst av utmattelse etter hjerneslag og etter traumatisk hjerneskade.

Det kan være ulike forklaringer på dette. Måleverktøyene er ikke like og måler ulikt $(4,14,36)$. Det er ingen gullstandard for valg av verktøy og heller ikke for valg av grenseverdi (cut off) for den enkelte skala. Prevalenstallene omfatter ulike populasjoner. Undersøkelsene kan ha ulike inklu- sjons- og eksklusjonskriterier, blant annet for de alvorligst skadede (54). De er derfor ikke uten videre sammenliknbare (4). Prevalensen vil kunne variere gjennom forløpet etter skade. Ulike måletidspunkter kan gi ulike prevalenstall. I en undersøkelse (41) fant man at prevalensen av utmattelse hos slagrammede var $51,5 \%, 64,1 \%$ og $69,5 \%$ ved henholdsvis innleggelse, et halvt og ett år etter slaget. Komorbide faktorers overlapping veies ulikt i analysene (42). Prevalenstallene for utmattelse kan derfor i ulik grad romme andre samvarierende tilstander (confounding factors).

Vi har konsentrert oss om utmattelse etter hjerneslag og etter traumatiske hjerneskader. Det er ikke umulig at denne tilstanden ved ulike sykdommer kan ha flere fellestrekk og muligens også noen felles bakenforliggende mekanismer. 
Å gi en oversikt over utmattelse etter hjerneslag og etter traumatisk hjerneskade er utfordrende fordi eksisterende litteratur spriker mye når det gjelder metodevalg og definisjoner. Til tross for disse utfordringene mener vi at det er viktig for leger som er $i$ kontakt med pasienter som har gjennomgått hjerneslag eller traumatisk hjerneskade å kjenne til den forskningen som tross alt foreligger, inkludert dens begrensninger. Vi har prøvd å formidle dagens status i denne artikkelen i lys av våre egne kliniske erfaringer.

\section{Konklusjon}

Med utgangspunkt i gjennomgått litteratur og vår egen kliniske erfaring synes fatigue/ utmattelse å være et vanlig forekommende symptom etter hjerneslag og etter traumatiske hjerneskader. Vi har lite systematisk kunnskap om hvordan pasientene følges opp i primærhelsetjenesten. Det er mangelfull kunnskap om etiologien og det mangler kunnskap om hva som er riktig behandling.

Gitt den betydelige implikasjonen symptomet har på pasientenes livsutfoldelse og livskvalitet, må mer forskning til for å sikre dem best mulig oppfølging både i primærhelsetjenesten og i spesialisthelsetjenesten.

\section{Andreas Schillinger (f. 1950)}

er spesialist i fysikalsk medisin og rehabilitering og overlege.

Forfatter har fylt ut ICMJE-skjemaet og oppgir ingen interessekonflikter.

\section{Frank Becker (f. 1969)}

er spesialist i fysikalsk medisin og rehabilitering, seksjonsoverlege og førsteamanuensis. Forfatter har fylt ut ICMJE-skjemaet og oppgir ingen interessekonflikter.

\section{Litteratur}

1. De Groot MH, Phillips SJ, Eskes GA. Fatigue associated with stroke and other neurologic conditions: Implications for stroke rehabilitation. Arch Phys Med Rehabil 2003. 84: 1714-20.

2. Chaudhuri $A$, Behan PO. Fatigue in neurological disorders. Lancet 2004; 363: 978-88.

3. Hoang CLN, Salle J-Y, Mandigout S et al. Physical factors associated with fatigue after stroke: an exploratory study. Top Stroke Rehabil 2012; 19: $369-76$.

4. Cantor F. Central and peripheral fatigue: exemplified by multiple sclerosis and myasthenia gravis. PM R 2010; 2: 399-405.

5. Lerdal A, Bakken LN, Kouwenhoven SE et al. Poststroke fatigue - a review. J Pain Symptom Manage 2009; 38: 928-49.

6. Chaudhuri A, Behan PO. Fatigue and basal ganglia. J Neurol Sci 2000; 179 (S 1-2): 34-42.

7. Ingles JL, Eskes GA, Phillips SJ. Fatigue after stroke. Arch Phys Med Rehabil 1999; 80: 173-8.

8. Staub F, Bogousslavsky J. Fatigue after stroke: a major but neglected issue. Cerebrovasc Dis 2001; 12: 75-81.

9. Ericsson A, Bremell T, Mannerkorpi K. Usefulness of multiple dimensions of fatigue in fibromyalgia. J Rehabil Med 2013; 45: 685-93.
10. Chalder T, Berelowitz G, Pawlikowska T et al. Development of a fatigue scale. J Psychosom Res 1993. 37: 147-53.

11. Hayes MHS, Patterson DG. Experimental development of the graphic rating method. Psychol Bull 1921; 18: 98-9

12. Likert R. A technique for the measurement of attitudes. Arch Psychol 1932; 140: 1-55.

13. Mead G, Lynch J, Greig C et al. Evaluation of fatigue scales in stroke patients. Stroke 2007; 38 $2090-5$

14. Dittner AJ, Wessely SC, Brown RG. The assessment of fatigue: a practical guide for clinicians and researchers. J Psychosom Res 2004; 56: 157-70.

15. Borgaro SR, Gierok S, Caples H et al. Fatigue after brain injury: initial reliability study of the BNI Fatigue Scale. Brain Inj 2004; 18: 685-90.

16. Ziino C, Ponsford J. Measurement and prediction of subjective fatigue following traumatic brain injury. J Int Neuropsychol Soc 2005; 11: 416-25.

17. Tseng BY, Gajewski BJ, Kluding PM. Reliability responsiveness, and validity of the visual analog fatigue scale to measure exertion fatigue in people with chronic stroke: a preliminary study. Stroke Res Treat 2010. E-publisert 16.5.

18. Lee KA, Hicks G, Nino-Murcia G. Validity and reliability of a scale to assess fatigue. Psychiatry Res 1991; 36: $291-8$

19. Krupp LB, LaRocca NG, Muir-Nash J et al. The fatigue severity scale. Application to patients with multiple sclerosis and systemic lupus erythematosus. Arch Neurol 1989; 46: 1121-3.

20. Schwartz JE, Jandorf L, Krupp LB. The measurement of fatigue: a new instrument. J Psychosom Res 1993: 37: 753-62.

21. Belza BL, Henke CJ, Yelin EH et al. Correlates of fatigue in older adults with rheumatoid arthritis. Nurs Res 1993; 42: 93-9.

22. Smets EM, Garssen B, Bonke B et al. The Multidimensional Fatigue Inventory (MFI) psychometric qualities of an instrument to assess fatigue. J Psychosom Res 1995; 39: 315-25

23. Fisk JD, Ritvo PG, Ross $L$ et al. Measuring the functional impact of fatigue: initial validation of the fatigue impact scale. Clin Infect Dis 1994; 18 lsuppl 1): S79-83.

24. Pawlikowska T, Chalder T, Hirsch SR et al. Popula tion based study of fatigue and psychological distress. BMJ 1994: 308: 763-6.

25. Loge JH, Ekeberg O, Kaasa S. Fatigue in the gene ral Norwegian population: normative data and associations. J Psychosom Res 1998; 45: 53-65

26. Bay E, de-Leon MB. Chronic stress and fatiguerelated quality of life after mild to moderate traumatic brain injury. J Head Trauma Rehabil 2011: 26: $355-63$

27. Tang WK, Chen YK, Mok V et al. Acute basal ganglia infarcts in poststroke fatigue: an MRI study. Jeurol 2010; 257: 178-82.

28. van der Werf SP, van den Broek HLP, Anten HWM et al. Experience of severe fatigue long after stroke and its relation to depressive symptoms and disease characteristics. Eur Neurol 2001; 45: 28-33.

29. Christensen D, Johnsen SP, Watt T et al. Dimensions of post-stroke fatigue: a two-year follow-up study. Cerebrovasc Dis 2008; 26: 134-41.

30. Carlsson GE, Möller A, Blomstrand C. Consequences of mild stroke in persons $<75$ years - a 1 -year follow-up. Cerebrovasc Dis 2003; 16: 383-8

31. Ziino C, Ponsford J. Vigilance and fatigue following traumatic brain injury. J Int Neuropsychol Soc 2006: 12: 100-10.

32. Norrie J, Heitger M, Leathem J et al. Mild traumatic brain injury and fatigue: a prospective longitudinal study. Brain Inj 2010; 24: 1528-38

33. Cantor JB, Bushnik T, Cicerone K et al. Insomnia, fatigue, and sleepiness in the first 2 years after traumatic brain injury: an NIDRR TBI model system module study. J Head Trauma Rehabil 2012; 27: E1-14

34. van der Naalt J, van Zomeren AH, Sluiter WJ et al. One year outcome in mild to moderate head injury: the predictive value of acute injury characteristics related to complaints and return to work. J Neuro Neurosurg Psychiatry 1999; 66: 207-13.
35. Olver JH, Ponsford JL, Curran CA. Outcome following traumatic brain injury: a comparison between 2 and 5 years after injury. Brain Inj 1996; 10: $841-8$

36. Englander J, Bushnik T, Oggins J et al. Fatigue after traumatic brain injury: Association with neuroendocrine, sleep, depression and other factors. Brain Inj 2010; 24: 1379-88.

37. Choi-Kwon S, Han SW, Kwon SU et al. Poststroke fatigue: characteristics and related factors. Cerebrovasc Dis 2005: 19: 84-90.

38. Naess $H$, Nyland $H I$, Thomassen $L$ et al. Fatigue at long-term follow-up in young adults with cerebral infarction. Cerebrovasc Dis 2005; 20: 245-50.

39. Ponsford JL, Ziino C, Parcell DL et al. Fatigue and sleep disturbance following traumatic brain injury-their nature, causes, and potential treatments. J Head Trauma Rehabil 2012; 27: 224-33.

40. Cantor JB, Ashman T, Gordon W et al. Fatigue after traumatic brain injury and its impact on participation and quality of life. J Head Trauma Rehabil 2008; 23: 41-51.

41. Schepers VP, Visser-Meily AM, Ketelaar M et al. Poststroke fatigue: course and its relation to per sonal and stroke-related factors. Arch Phys Med Rehabil 2006: 87: 184-8.

42. Duncan F, Kutlubaev MA, Dennis MS et al. Fatigue after stroke: a systematic review of associations with impaired physical fitness. Int J Stroke 2012; 7 157-62.

43. van Zomeren AH, Brouwer WH, Deelman BG. Attentional deficits: the riddles of selectivity, speed, and alertness. I: Brooks D, red. Closed head injury: psychological, social, and family consequences. New York: Oxford University Press; 1984: 74-107

44. Kohl AD, Wylie GR, Genova HM et al. The neural correlates of cognitive fatigue in traumatic brain injury using functional MRI. Brain Inj 2009; 23: 420-32.

45. Bushnik T, Englander J, Wright J. Patterns of fatigue and its correlates over the first 2 years after traumatic brain injury. J Head Trauma Rehabil 2008; 23: 25-32.

46. McGeough E, Pollock A, Smith LN et al. Interventions for post-stroke fatigue. Cochrane Database Syst Rev 2009; 3: CD007030.

47. Dijkers MP, Bushnik T. Assessing fatigue after traumatic brain injury: an evaluation of the HIV Related Fatigue Scale [corrected]. J Head Trauma Rehabil 2008; 23: 3-16.

48. Bay E, Xie Y. Psychological and biological correla tes of fatigue after mild-to-moderate traumatic brain injury. West J Nurs Res 2009: 31: 731-47.

49. Clarke A, Barker-Collo SL, Feigin VL. Poststroke fatigue: does group education make a difference? A randomized pilot trial. Top Stroke Rehabil 2012; 19: $32-9$

50. Choi-Kwon S, Choi J, Kwon SU et al. Fluoxetine is not effective in the treatment of post-stroke fatigue: a double-blind, placebo-controlled study. Cerebrovasc Dis 2007: 23: 103-8.

51. Jha A, Weintraub A, Allshouse $A$ et al. A randomized trial of modafinil for the treatment of fatigue and excessive daytime sleepiness in individuals with chronic traumatic brain injury. J Head Trauma Rehabil 2008; 23: 52-63.

52. Brioschi A, Gramigna S, Werth E et al. Effect of modafinil on subjective fatigue in multiple sclerosis and stroke patients. Eur Neurol 2009; 62 243-9.

53. Watt T, Groenvold M, Bjorner JB et al. Fatigue in the Danish general population. Influence of sociodemographic factors and disease. J Epidemiol Community Health 2000; 54: 827-33.

54. Borgaro SR, Baker J, Wethe JV et al. Subjective reports of fatigue during early recovery from traumatic brain injury. J Head Trauma Rehabil 2005; 20: $416-25$

Mottatt 27.2. 2014, første revisjon innsendt 15.7. 2014, godkjent 2.12. 2014. Redaktør: Trine B. Haugen. 